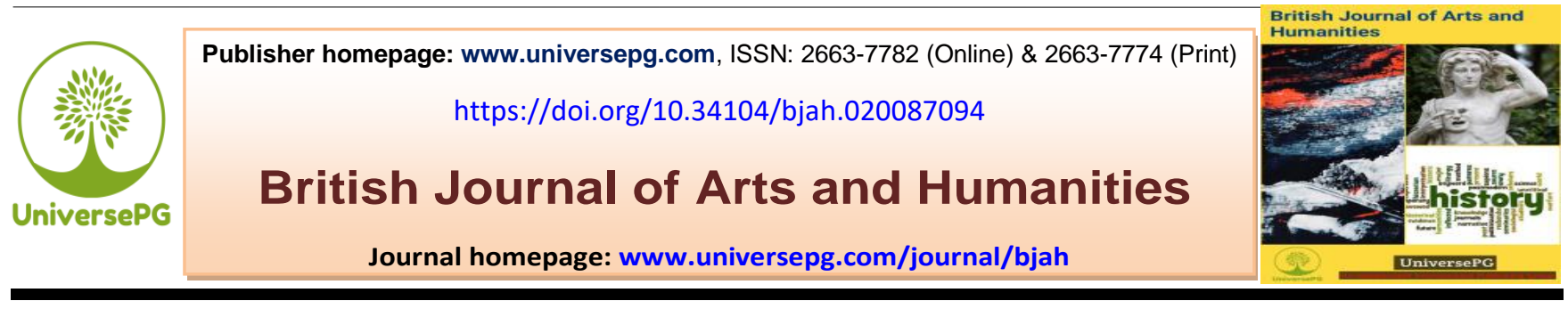

\title{
Impacts of Unemployment on Graduates in Bangladesh: A Case Study
}

\author{
Md. Harunur Rashid ${ }^{1 *}$, and Md. Ashraful Islam ${ }^{2 * *}$ \\ ${ }^{1}$ Department of Public Administration and Governance Studies, Jatiya Kabi Kazi Nazrul Islam University \\ (JKKNIU), Trishal, Mymensingh, Bangladesh; and ${ }^{2}$ Master of Business Administration, University of Greenwich, \\ London, United Kingdom. \\ *Correspondence: harun_du.rashid92@yahoo.com (Md. Harunur Rashid, Lecturer, Department of Public Administration and \\ Governance Studies, JKKNIU, Trishal, Mymensingh, Bangladesh). \\ **Correspondence: aislam208@ outlook.com (Md. Ashraful Islam, MBA Student, University of Greenwich, London, United \\ Kingdom).
}

\begin{abstract}
The study attempts to explore the impacts of unemployment; how state of unemployment is becoming the cause of social, economic, physical, personality, and psychological costs on the unemployed graduates with identification of reasons of unemployment in Bangladesh. The study area was the unemployed graduates of the social science faculty of the University of Dhaka. The study followed qualitative approach through using case study method. Capacity mismatch, corruption, incapacity of the graduates, absence of job specialization, outdated curriculum were the leading reasons of unemployment, the study identified. The impacts of unemployment are invariably alike on graduates-mental depression, embarrassment, socio-economic vulnerability, erosion of inner potentiality, degradation of personality and frustration. The study explored that sense of selfesteem erodes due to peer group pressure and their attitudes towards unemployed graduates. The findings significantly guide that Bangladeshi graduates, who hailed from lower and middle strata, lack in entrepreneurial spirit and are bound in cyclical craziness to secure a job primarily a government job. It recommends for further evaluation of the Bangladesh's education systems, focus of higher education which will meet the capacity mismatch between market demands and education; and changes in attitudes-overindulgence on government job, associated with cultural factors, must be needed to minimize the vulnerabilities. Academia, learners, policy makers, scholars, policy advocates will get significant insight from the findings of the study.
\end{abstract}

Keywords: Graduate unemployment, Impacts of unemployment, Bangladesh, Case study, University of Dhaka.

\section{INTRODUCTION:}

Higher education acts as catalytic force to obtain sustainable economic growth by providing required skills and abilities which lead further research and development as well as ensure sustainable growth (Lim, 2011). In promoting lifelong learning opportunities to all, achieving inclusive quality education is an important vehicle to achieve Sustainable

UniversePG I www.universepg.com
Development Goals (SDGs); goal four set targets to obtain quality education within 2030 (UNDP, 2015). Though education draws universally global impetus as fundamental weapon to reduce unemployment, International Labor Organization (ILO) estimates that 172 million people remain unemployed around the world scoring 5 percent (ILO report, 2019). Though the rate of unemployment in Bangladesh remains in 
low level $(5.0 \%)$, the rate of underemployment is $28.7 \%$ which is showing substantial grim scenario of employment status (BBS Employment Report, 2019). Economic Intelligence Unit (EIU), sponsored by British Council, estimates that the rate of graduate unemployment in Bangladesh is $47 \%$, generated media storm and made concern among the citizens of Bangladesh (Asadullah, 2014). 34\% graduates are unemployed who earned first class in their Bachelor and Master degree, Bangladesh Institute of Development Studies (BIDS) survey reveals most recently ('34\% Unemployed instead of having First Class', 2109).

Whatever the causes of unemployment in Bangladesh, Rashid (2019) found in study that corruption, capacity mismatch, outdated curricula, small job market, flawed education system, absence of job specialization, political influence in the recruitment process were the leading reasons for graduates unemployment in Social Science Faculty background students, but the cost of unemployment is manifold. It includes social, economic, personal (self-esteem), chronic psychological and health cost on unemployed persons. Schaufeli \& Yperen (1992) found that unemployment is associated with psychological distress irrespective of male or female, who become unemployed more than two years. Hasan and Rabbi (2018) quoted Zia Rahman, chairperson of the Department of Criminology at Dhaka University, said these fatal incidents are linked with mental depression and mental instability following several issues like unemployment, social insecurity, romantic failure, and family dispute'. The study, following quailtative approach, attempts to explore what the impacts are being bearing by the unemployed graduates on-economical, social, psychological, personal (self esteem, inner bleeding), career due to state of unemployment, along with investigating to identify the causes of unemployment.

\section{Literature Review:}

The word 'unemployment' defined in Oxford Dictionary as the fact of a number of people not having a job or the number of people without a job. ILO defined 'employment' as comprising all persons in working age (15 years and older) who are working a specified brief period in a week or a day in two categories- paid employment or self employment. It defined 'unemployment' as working age people who are job seekers or eager to work but they are not getting access for paid job one hour in a week.

Neazy (2019) argued that lack of placement policy, skill mismatch in managerial and technical arena in this fourth industrial revolution, and poor skill development results joblessness which breeds depression. Continued declining employment elasticity, inability of economy to generate employment opportunities as per economic growth, is causing unemployment in Bangladesh (Byron, 2019). Jahan (2006) explained the recruitment procedures in the public administration of Bangladesh and the extent and impact of politicization examined and found political consideration plays key role. The three main problems in the recruitment and selection process are quota, faulty examination procedure; politicization and corruption (Jahan, 2012). Zafrullah (2018) analyzed the difficulties-social and cultural barriers of women in joining civil service and he found a number of difficulties for women like uneven competition with competent male contestants, systematic discrimination and varied nature of odds.

Economists identified two types of adverse effects of unemployment-output forgone that could be produced and psychological distress. Goldsmith et al. (1996) found that unemployed male youths fail to influence locus of control while young women belief-state of unemployment declines personal efficacy and leads self-perceptions of helplessness. Findings suggested that joblessness is accompanied with psychological scarring. Schaufeli \& Van Yperen (1992) observed that the reaction on unemployment is alike irrespective of male or female. Graduates who are comparatively less vulnerable psychologically are more likely to get employed than more psychologically distressed graduates; group specific aspects like level of education and cultural, structural context influence on the perceptions, the study observed. Employment status affects one's mental health-the move from unemployment status to employment has reliable effects on mental well-being (Murphy \& Athanasou, 1999). Unemployment has significant social costs 
which vary because of variance in the regions, duration of unemployment.

Rates of unemployment might provide distorted views on social costs (Gorjon et al., 2018). Shamir (1986) showed on the cross-sectional study and longitudinal analysis that employment status affects depressive effects, morale and anxiety. Self-esteem moderates relationship between employment status and psychological well-being while low self-esteem individuals are more sensitive to employment status than high self-esteem individuals. Unemployment has harmful impact on happiness and negative effects on individuals even after intervention program like income support program; such initiative has little impact to bring happiness on the unemployed persons in Germany (Winkelmann \& Winkelmann, 1995).

Suicide breeds from high unemployment rate which is the ultimate cost of unemployment (Schapiro \& Ahlburg, 2015). High rates of depression, anxiety and stress-scored $54 \%, 65 \%$, and $59 \%$ respectively, on medical graduates in Bangladesh are prevalent. Social and cultural factors as well as other common elements lead psychiatric disturbances like depression, anxiety and stress among the unemployed graduates (Rafi et al., 2019). The study attempts to investigate the impacts of unemployment on the social science background graduates followed by case study methods in University of Dhaka, Bangladesh. There has explicit literature gap in the above literatures which the study attempts to be dealt in.

\section{Objective of the Study:}

The primary objectives of the study were to explore the impacts of unemployment on Graduates and to investigate the reasons of unemployment in Bangladesh. The study embraces following specific objectives-

a. To explore the reasons of graduates' unemployment through unveiling their inner perceptions and self-realizations.

b. To investigate social, economic, personal (self-esteem, personality), psychological impacts on the unemployed graduates in the existing socio-cultural context of Bangladesh.

\section{METHODOLOGY:}

The study is qualitative in nature where the location of the study was in the University of Dhaka, regarded as the top echelon of the academic institution. Qualitative research collects data from different multiple sources including interviews, observations, and documents developing holistic account through reporting multiple perspectives (Creswell, 2008).

Case study method was used in investigation while checklist was used as data collection instrument. Indepth face to face interviews were taken from eight graduates, passed from the different departments of social science faculty of the University of Dhaka who were become unemployed at least one year after completion of their graduation. Eight cases were selected purposively because of convenience to get required information from the respondents and pseudonyms were used in the study having with written and verbal confidential guarantee about their interviews. Observation method was also used for exploring inner expression, perception, and psyche due to state of unemployment.

Thematic approach was used to present the findings of the study. Relevant literatures were collected from secondary sources including books, journals, articles, news, interviews, internet materials, etc. Written and oral guarantee were given to the respondents against misusing information with the aim of maintaining ethical standard in social science research.

\section{RESULTS:}

\section{Socio-Economic Background of the Respondents -} All of the graduates who delivered their inner voice about the impact of unemployment are backed from the middle and lower-middle class family where most of them are from lower-middle class family. It is significant that majority of the families are educated and well conscious about the education. Almost all came from the villages. Economic constraints are driving away to all the families of the unemployed graduates. They are facing hardship to cope up with the expenses in the pace of monthly income where graduates' brothers and sisters are also studying mostly. Besides, every family has social acceptance and status in the society due to the educational 
qualification. It was noticed that most of the family' profession were in small scale job or small business like school teaching, service holder, NGO workers, $2^{\text {nd }}$ and $3^{\text {rd }}$ class government job, the scenario is reflecting the socio-economic status of the graduates family. The result is revealing the nature of class structure and their position in the society of family of public university students in Bangladesh. This portion of society is struggling hard for better future where education is the only weapon to secure a job.

Respondents' Views on the Reasons of Graduate Unemployment - Graduates are being unemployed due to some undeniable reasons which disclosed in their assessment. Corruption plays role in securing government job alleged by those who faced embarrassing situation in the recruitment process. One of the graduates opined -

"I was embarrassed in the viva voce for my educational background”.

The same tune was echoed in another respondent's voice. He said-

"I had no political affiliation, and I had no money muscle to ensure my qualification. It is unfortunate that I was embarrassed by the selection board'

Subject can't avoid the responsibility where one graduate mentioned that his subject has not specific job area in the market as well as few of them alleged to the little employability of their subjects. One graduate expressed in the following way -

"At the beginning, I had a happy life. Before I came here, I thought I could learn many things, and I could get a job after completing my graduation. But when I came here, I have faced some bad experiences. Our department was not rich",

Graduates criticized harshly for absence of job specialization in Bangladesh which is breeding unemployment. In the speech of graduates -

"The graduates of linguistic, Arabic etc. can go to the Administration Cadre, how it looks like!"

Unemployed graduates raised questions on the curriculum of the university which lacks interaction with the needs of the job market, methods of teaching as well. There is little consistency of courses outline having with practical deficiency with the demand of the job market. Consequently, subject knowledge cannot be able to secure optimum outcome in the job exam. Aminul Islam, graduate from sociology department opined -

"I think I did not pass the exam because the curriculum of my department is outdated and it is not consistent with the job market. Now I am suffering because of that"

Few job candidates confessed that he/she has lacking in the preparation especially in the mathematics and in English which are keys to secure a job. Mohidur Rahman said -

\section{"I am not good enough at mathematics"}

Another respondent confessed that-

"Not to cope with the present job market and little scope of job for social science graduate, lacking in English spoken \& to express myself."

Lacking of proper career counseling, small job market was also exacerbating the suffering of unemployed, the study indentified. Incapacity of the graduates to bag high salaried job was also significant reason for being unemployed.

\section{Impacts of Unemployment on Graduates: Eroding} Inner Strength - Society and family expectations remain lofty, counting the educational year when they will take responsibility of the family, but they often are unknown about the job market reality, on the graduates as they earned the degree from the country's top echelon of academic institution. This growing aspiration hammer graduates further. If he or she is elder son/daughter of the family as well as his/her family prime earning member got retirement, at that time the unbearable pressure mounts. Saiful Islam expressed his feelings in this way -

"As an elder son in the family, I feel huge pressure that when $i$ will take care of family and unburden my old farmer father. I feel more embarrassed to want money after completing academic studies." 
Unemployed graduates had to struggle to get married where they had to bear the cost of marriage in some cases. Peer group pressure, pressure from family and relatives, social pressure instigates further vulnerability which has severe mental and health cost. Primarily, pressure comes from family through consistent hammering. It is significant findings that unemployed graduates feel more embarrassment when they have to face their friends who secured job. In the voice of few respondents, the real scenario was unveiled in the study.

Ehsan said - "I feel more embarrassment to face my classmates and friends who have got job and it is creating self-humiliation rather facing my family and the society".

Mohidur Rahman opined- "I feel more embarrassment when someone asks, "what are you doing now".

Prince says- "when someone is acquainted with me to know about me and he knows that I am unemployed. It is much embarrassing for me"

Russel Ahmed expressed himself- "I feel humiliation to face my relative and friends who have got job. Some of my younger brother got job I have not. It is more frustrating".

Frustration is breeding and is impacting contagiously which cost psychologically. Thus, psychological pressure leads cost in health and moral of the graduates. Depression which erodes the inner potentiality of the human being is the result. Cumulative negative impact of the unemployment on promising bulk of human resources is caused lacking in confidence to fight further to secure job, making vulnerable further. In this way, unemployment is creating a vicious cycle costing socially, economically, health; and leading lost generation. Study unveiled the inner feelings of unemployed graduates what the grave scenario it is revealed as quoted in the following.

Sayeda Shanjida Alam (visually impaired) is the exstudent of department of sociology of the University of Dhaka. She is $26+$ years old still unmarried. She said -

UniversePG I www.universepg.com
"Every morning I adversely feel that another long and tiring day is coming to me".

This state creates an unbearable mental pressure to her, and it is increasing day by day along with other social and family pressure. Because of patriarchal socio- cultural pattern of Bangladesh it has still quite difficult for a girl to get higher education. So it can be easily assumed that how difficult it may be for a woman to be jobless after completing her graduation from the best university of the country.

Aminul Islam revealed his feelings how he is bearing brunt of mental pressure. He expressed -

"When I come back home and see the gloomy face of my parents and sister I fell that I am good for nothing. I wish I could get a job very soon"

The study identified that state of unemployment does have explicit psychological, social, economic and personal cumulative costs on graduates. Investigation explored that class structure of respondents in the society, belonging in the lower-middle class stratum, excessive dependence on the limited sources of income, excessive expectation on graduates, and capacity mismatch with the market demands made the situation worse. The outright consequences of the state of unemployment are- economic vulnerability, frustration, embarrassment, degrading personality and self-esteem, psychological pressure, physical and emotional harms, erosion of potentiality and confidence.

\section{DISCUSSION:}

The study unveiled that the tendency and nature of psyche structure of the graduates on choosing the job field where public university graduates, hailed from middle or lower rung of the society, prone to public sector jobs. Significantly, they are representing the ingrained notion of Bangladeshi society largely on the government jobs. Rashid (2020) found that majority of the social science background graduates ticked Bangladesh Civil Service (BCS) as first priority. The Daily Star, national daily, reports shows the craziness of jobseekers how they are using libraries. The reports mentioned that most of the library goers are jobseekers and they bring guide, notebooks for taking their job 
preparation instead of reading library books while only few use library books. The situation is similar in others capital's library. Though the number of library goers has been increased but the number of genuine knowledge seekers has been declined sharply ('Academic books on shelves', 2020). A total 4, 12,532 candidates applied in the $40^{\text {th }}$ BCS against 1903 cadre showing severity of competition to secure first class gazette office post (' $40^{\text {th }}$ BCS: 20, 277 candidates', 2019).

The result of this craziness is frustration who failed to secure a cadre. Frustration creates further vulnerabilities in many forms and it is intensified when the societal context is convenient to create humiliating environment for struggling graduates. As a result, due to excessive concentration, they remain unemployed. The status of unemployment begets a number cumulative negative impact on health, psychology, personality, social status, economic dependency and so on. Ultimately, it leads depression, embarrassment, anxiety and erodes the inner potentiality of the candidates, the study found. Unemployment has harmful impact on happiness as well as negative effects on individuals even after taking intervention program like income support programs (Winkelmann \& Winkelmann, 1995). Suicide occurred from high unemployment rate which is the ultimate cost of unemployment (Schapiro \& Ahlburg, 2015). A study found that high rates of depression, anxiety and stress on medical graduates in Bangladesh are prevalent. Social and cultural factors as well as other common elements lead psychiatric disturbances like depression, anxiety and stress among the unemployed graduates (Rafi et al., 2019). Investigation revealed that there have explicit social, economic, health, and mental costs due to state of unemployment which is invariably true for unemployed graduates.

Therefore, the study explored that the trust on recruitment process in Bangladesh in government job remains low. Political influence in recruitment process erodes the trust of jobseekers on recruiting agencies. Outdated curriculum and traditional method of teaching create capacity mismatch with the demand of job market. Incapacity of the graduates, poor command in English and mathematics, poor career UniversePG I www.universepg.com planning, non-applicability of subjective knowledge in the changed job market and low demand of few social science subjects caused unemployment. Lack of placement policy, skill mismatch in managerial and technical arena in this fourth industrial revolution, and poor skill development are resulting joblessness which breeds depression (Neazy, 2019).

\section{CONCLUSION AND POLICY IMPLICATIONS:}

Whatever the reasons of being unemployed throughout the years after completion of graduation in Bangladesh - small job market, absence of job specialization, outdated curriculum, incapacity of the graduates, poor career planning, corruption; the impacts of being unemployed are invariably alike on graduates-mental depression, embarrassment, socio-economic vulnerability, erosion of inner potentiality, degradation of personality and frustration. The findings guide significantly that Bangladeshi graduates, who hailed from lower and middle strata, lack in entrepreneurial spirit and are bound in cyclical craziness to secure a job primarily a government job. The scenario is showing the socio-economic context and psyche structure of these strata of society which is causing to create further vulnerability on graduates in the duration of unemployment. The study has a number of limitations. Firstly, it is difficult to generalize the findings of the study on all kinds of graduates as the study focused merely on the social science graduates. Secondly, the research was conducted on the public university graduates; it is recommending for further investigation to explore the reasons and impacts of graduate unemployment including different back ground graduates. Thirdly, the case experiences taken in the study might not applicable for others graduates who are seeking job.

Above all, the study explored that the social, economic, mental, personal costs are invariably same on graduates in the duration of unemployment. This Study is recommending a number of policy interventions and strategic initiatives for concerned authorities.

a. Curriculum and methods of teaching of the university should be updated based on market demands including collaboration with private sector to prevent capacity mismatch as well as 
education system must be consistent with changing demands of the market and technological development.

b. Entrepreneurial spirit must be injected from primary education by setting contents related to entrepreneurship while job security and social recognition of private sector are crying need to prevent craziness of the graduates on government jobs; which ultimately will lead transformation of the notion of the society and will cause to soothe the vulnerabilities of the graduates in the duration of unemployment.

c. 'Failing to be a BCS cadre or securing a government job is a disaster'-this mentality must be changed. Counseling and training on technology will create new horizon of opportunities and hope. Government and university authority must be taken required initiatives in this regard.

d. Finally, national strategic human resources plan is not luxury requirement in the changed context of Bangladesh; national strategic human resources plan needs to be formulated urgently concerning with global vision to meet the challenges in years to come and whole education system must be aligned with that plan.

\section{ACKNOWLEDGEMENTS:}

We would like to thank our lovely family members for their tireless support and courage to complete the article within timeframe. We are offering gratitude to the respondents, graduates of Social Science Faculty of the University of Dhaka for their warm response.

\section{CONFLICTS OF INTEREST:}

It is being declared that there is no conflict of interest about the authorship and authenticity of this article.

\section{REFERENCES:}

1. Academic books on shelves, BCS guides on tables, (2020), The Daily Star, March 01, viewed March 25, 2020.

https://www.thedailystar.net/frontpage/news/aca demic-books-shelves-bcs-guides-tables-1874671

2. Asadullah, N. (2015), 'Is graduate unemployment rate really 47\%', The Daily Star, March 08, viewed April 03, 2020.
3. Byron, K. R. (2019), 'High growth, fewer jobs: Despite high economic growth, agriculture, industry sectors unable to create enough jobs, shows govt study', The Daily Star, August 17, viewed March 22, 2020.

https://www.thedailystar.net/frontpage/news /high-growth-fewer-jobs-1786315

4. Creswell, W. J. (2008), Research Design: Qualitative, Quantitative, and Mixed Methods Approaches, Sage Publications, New Delhi, India.

5. Goldsmith, H. A, Veum, J, \& Darity, W. (1996), 'The Psychological Impact of Unemployment and Joblessness', Journal of Socio-Economics, 25(3), pp. 333-358. https://www.sciencedirect.com/science/artic le/abs/pii/S1053535796900098

6. Gorjon, L. Rica la de, \& S. Villar, A. (2018). 'The Social Cost of Unemployment: The Spanish Labor Market from a Social Welfare Approach', I Z A Institute of Labor Economic, Deutsche Post Foundation. http://ftp.iza.org/dp11850.pdf

7. Hasan, K. \& Rabbi, R. A. (2018), 'Examining the alarming suicide trends in Bangladesh', May 08, viewed March 2020.

https://www.dhakatribune.com/opinion/s pecial/2018/05/08/examining-alarming suicide-trends-bangladesh

8. International Labour Organization, World Employment Social Outlook 1919-2019, ILO.

https://www.ilo.org/wcmsp5/groups/public/--dgreports/---dcomm/---publ/documents/ publication/wcms 670542.pdf

9. Jahan, F. (2006) 'Public Administration in Bangladesh, Background Paper for the State of Governance in Bangladesh 2006', Centre for Governance Studies, BRAC University, Dhaka, Bangladesh.

10. Jahan, M. (2012), 'Recruitment and Selection Process in Bangladesh Civil Service: A Critical Overview; Public Policy and Administration Research, Vol.2, No.5. 
11. Lim, H. (2010), 'Estimating Psychological Impact of Unemployment: The Case of Malaysian Graduates', Malaysian Journal of Economic Studies, 47(1): 33-53. https://mjes.um.edu.my/article/view/2832

12. Murphy, C. G., \& Athanasou, A. J. (1999), 'The effect of unemployment on mental health', J. of Occupational and Organizational Psychology, 72, 83-99. https://onlinelibrary.wiley.com/doi/abs/10.1 348/096317999166518

13. Neazy, N. S. (2019), 'Rise of the Graduate Unemployed', The Dhaka Tribune, June 08, viewed April 20, 2020.

https://www.dhakatribune.com/opinionl/oped/2019/06/28/rise-of-the-educated-un employed

14. Rafi, A. M., Mamun, A. M., Hsan, K., \& Gozal, D. (2019). 'Psychological Implications of Unemployment Among Bangladesh Civil Service Job Seekers: A Pilot Study', Frontiers in Psychiatry, July-2019, Vol. 16. https://doi.org/10.3389/fpsyt.2019.00578

15. Rashid, HM (2019). 'Why Bangladesh Civil Service (BCS) Remains Lucrative as Career? A Gender Based Analysis', JKKNIU Journal of Social Science, Vol. 02, June-2019.

16. Schaufeli, B. W. \& VanYperen, W. N. (1992). 'Unemployment and Psychological Distress among Graduates: A Longitudinal Study', Journal of Occupational and Organizational Psychology, 65, p. 291-305.

https://onlinelibrary.wiley.com/doi/abs/10.1 111/j.2044-8325.1992.tb00506.x
17. Schapiro, O. M., \& Ahlburg, A, D. (1982), 'Suicide: The Ultimate Cost of Unemployment', J. of Post Keynesian Economics, 5: 2, pp. 276-280. https://www.tandfonline.com/doi/pdf/10.10 80/01603477.1982.11489362?needAccess $=\mathrm{t}$ rue

18. Shamir, B. (1986), 'Self-Esteem and Psychological Impact of Unemployment, Social Psychology Quarterly, 49(1), p. 6072.

https://www.jstor.org/stable/2786857?seq=1

19. Sustainable Development Goals (SDGs), (2015), United Nations Development Program (UNDP), viewed March 25, 2020.

20. Winkelmann, I., \& Winnkelmann, R. (1995), 'Happiness and Unemployment: A panel data analysis for Germany', Applied Economics Quarterly, 4(4), 293-307. http://www.econ.uzh.ch/dam/jcr:1b71ecfbf662-4a49-bb34-f95153b619d4/kopo.pdf

21. Zafrullah, H. (2002), 'Through the Brick Wall, and the Glass Ceiling: Women in the Civil Service in Bangladesh', Gender Work and Organization. https://doi.org/10.1111/1468-0432.00107

22. ' $40^{\text {th }}$ BCS: 20, 277 candidates pass preliminary test', 2019, The Daily Prothom Alo (Online English Version), July 25, viewed April 24, 2020. https://en.prothomaloo.com/youth/40thBCS-20-277-candidates-pass-preliminarytests

23. '34\% Unemployed instead of having First Class', (2019), The Daily Prothom Alo, December 08, viewed April 25, 2020.

Citation: Rashid MH and Islam MA. (2020). Impacts of unemployment on graduates in Bangladesh: a case study, Br. J. Arts Humanit., 2(5), 87-94. https://doi.org/10.34104/bjah.020087094 @) 